\title{
In utero heat stress decreases calf survival and performance through the first lactation
}

\author{
A. P. A. Monteiro, S. Tao, I. M. T. Thompson, and G. E. Dahl ${ }^{1}$ \\ Department of Animal Sciences, University of Florida, Gainesville 32611
}

\section{ABSTRACT}

Calves born to cows exposed to heat stress during late gestation (i.e., the dry period) have lower birth weight and weaning weight and compromised passive immune transfer compared with those born to dams that are cooled. However, it is unknown if heat stress in utero has carryover effects after weaning. The objective was to evaluate the effect of heat stress (HT) or cooling (CL) in late gestation dairy cows on the survival, growth, fertility, and milk production in the first lactation of their calves. Data of animals obtained from previous experiments conducted during 5 consecutive summers in Florida were pooled and analyzed. Cows were dried off $46 \mathrm{~d}$ before expected calving and randomly assigned to 1 of 2 treatments, HT or CL. Cooled cows were housed with sprinklers, fans, and shade, whereas only shade was provided to HT cows. Within $4 \mathrm{~h}$ of birth, $3.8 \mathrm{~L}$ of colostrum was fed to calves from both groups of cows. All calves were managed in the same manner and weaned at $49 \mathrm{~d}$ of age. Birth weight and survival of 146 calves $(\mathrm{HT}=74$; $\mathrm{CL}=$ 72) were analyzed. Additionally, body weight, growth rate, fertility, and milk production in the first lactation from 72 heifers ( $\mathrm{HT}=34 ; \mathrm{CL}=38)$ were analyzed. As expected, HT calves were lighter (means \pm SEM; $39.1 \pm 0.7$ vs. $44.8 \pm 0.7 \mathrm{~kg}$ ) at birth than CL calves. Cooled heifers were heavier up to 1 yr of age, but had similar total weight gain (means \pm SEM; $305.8 \pm 6.3$ vs. $299.1 \pm 6.3 \mathrm{~kg}$, respectively) compared with HT heifers. No effect of treatment was observed on age at first insemination (AI) and age at first parturition. Compared with CL heifers, HT heifers had a greater number of services per pregnancy confirmed at d 30 after AI, but no treatment effect was observed on number of services per pregnancy confirmed at d 50 after AI. A greater percentage of CL heifers reached first lactation compared with HT heifers (85.4 vs. 65.9\%). Moreover, HT heifers produced less milk up to 35 wk of the first

Received February 22, 2016.

Accepted June 8, 2016.

${ }^{1}$ Corresponding author: gdahl@ufl.edu lactation compared with CL heifers (means \pm SEM; $26.8 \pm 1.7$ vs. $31.9 \pm 1.7 \mathrm{~kg} / \mathrm{d}$ ), and no difference in body weight during lactation was observed (means \pm SEM; HT: $568.4 \pm 14.3 \mathrm{~kg}$; CL: $566.5 \pm 14.3 \mathrm{~kg}$ ). These data suggest that heat stress during the last $6 \mathrm{wk}$ of gestation induces a phenotype that negatively affects survival and milk production up to and through the first lactation of offspring.

Key words: calf, dry period, heat stress, postnatal performance

\section{INTRODUCTION}

Heat stress has substantial negative effects on dairy productivity through direct reductions on DMI and milk yield (Collier et al., 2006). Indeed, the financial effect of heat stress on the US dairy industry is estimated to be almost $\$ 1$ billion annually (St-Pierre et al., 2003). For the most part, however, the negative effects of heat stress noted previously were restricted to consideration of the lactating cow (Collier et al., 2006). More recent work has detailed the potential negative effect of dry period heat stress on subsequent performance of the cow (Tao and Dahl, 2013), but nothing is known with regard to long-term effects of in utero heat stress on the developing calf.

Calves born to cows exposed to heat stress during the dry period have lower birth weight (Collier et al., 1982; Tao et al., 2012), weaning weight, and compromised passive immune transfer (Tao et al., 2012) compared with those born to dams that are cooled. Moreover, Tao et al. (2012) observed decreased total plasma protein and hematocrit and compromised cellular immune function in calves born to heat stressed cows relative to calves born to cooled dams. Previous studies show that heat stress during gestation decreases uterine blood flow (Oakes et al., 1976; Reynolds et al., 2005) and placental weight (Alexander and Williams, 1971), suggesting an impairment of fetal growth. Additionally, Thompson et al. (2013) observed that cows heat stressed during the dry period had lower plasma pregnancy-specific protein $\mathrm{B}$ concentration during the last week of pregnancy compared with cooled cows, which also reflects altered placental development. 
Postnatal metabolism may also be compromised by late gestation heat stress. Lambs born to ewes that were heat stressed in mid-gestation have a higher insulin response to glucose (Yates et al., 2011) and lower lipolytic response to adrenergic stimulation compared with those from thermoneutral ewes (Chen et al., 2010). Despite these metabolic differences, the overall postnatal growth rate is similar to normothermic control lambs (Chen et al., 2010), which indicates that body composition may be different. Such differences in metabolism may manifest as altered performance later in life. However, the effect of heat stress in utero during late gestation on future performance of the heifer related to reproduction and milk production is still not known. Our study was designed to investigate possible carryover effects of maternal heat stress during late gestation on growth, survival, fertility, and milk production in the first lactation of their offspring. Specifically, we tested the hypothesis that in utero heat stress in late gestation would limit survival and lactation performance of mature dairy cows relative to calves that were born to dams cooled in late gestation.

\section{MATERIALS AND METHODS}

\section{Animals and Data Collection}

Data of animals obtained from 5 previous experiments conducted during 5 consecutive summers were pooled and analyzed. The experiments took place at the Dairy Unit of the University of Florida (Hague) during the period of 2007 to 2011. Multiparous Holstein cows were dried off $\sim 46 \mathrm{~d}$ before expected calving date and blocked on mature equivalent milk production of the previous lactation, and then randomly assigned to 1 of 2 treatments, heat stress $(\mathbf{H T})$ or cooling [CL; see do Amaral et al. (2009) for specifics related to the treatment of dams]. Of all the calves included in the study, most were conceived through AI, but some were conceived through in vitro fertilization (IVF) and those were evenly distributed between treatments $(\mathrm{HT}=23.0$ vs. $\mathrm{CL}=18.1 \% ; P=0.54)$. Oocytes were obtained from slaughterhouse ovaries of Holstein cows, which we assumed were of industry average genetic potential. Semen used for the IVF and AI procedures originated from 35 different sires, which were selected according to the normal farm protocol, and were randomly distributed between treatments. The semen used for IVF and AI procedures was not from the same sires. Specifically, for the heifers followed into the first lactation ( $\mathrm{n}=$ 64 ), semen was from 22 different sires and there was no difference between treatments for sire PTA for milk production (means \pm SEM; CL: $448.7 \pm 51.0$ vs. HT: $479.7 \pm 51.0 \mathrm{~kg} ; P=0.65)$. Dams of the heifers that were followed through the first lactation had similar mature-equivalent milk production in the previous lactation (HT: 10,999 vs. CL: $10,760 \mathrm{~kg} ; P=0.55$ ). After dry off CL cows were housed in a freestall barn with sprinklers, fans, and shade, whereas only shade was provided to HT cows residing in the same barn. In the CL treatment, fans ran continuously, whereas sprinklers turned on automatically for $1.5 \mathrm{~min}$ at 6 -min intervals when ambient temperature exceeded $23.9^{\circ} \mathrm{C}$. After calving, cows from both treatments were housed in the same freestall barn, cooled by sprinklers and fans. Therefore, the calves born to those cows were HT or cooled CL in utero during the final $\sim 46 \mathrm{~d}$ of gestation. Within $4 \mathrm{~h}$ after birth, calves from both groups of cows were separated from their dams, weighed with a digital scale, and then fed $3.8 \mathrm{~L}$ of colostrum. Colostrum was collected either from the dam or from a pool depending on the year, but all calves from each treatment in any year were fed colostrum sourced in the same way. All calves were individually housed in hutches and water and starter grain were provided ad libitum.

Pasteurized milk was fed twice a day (0600 and 1400 h). From d 1 to 29 calves were fed $1.9 \mathrm{~L}$ per feeding, increasing to up to $3.8 \mathrm{~L}$ per feeding from d 30 to 41. Pasteurized milk included waste milk from the herd and colostrum with a low score (i.e., $<50 \mathrm{~g} / \mathrm{L}$ measured by a colostrometer). Pasteurization was accomplished by heating the milk to $63^{\circ} \mathrm{C}$ for $45 \mathrm{~min}$. Calves were weaned gradually, starting at d 42 and ending at d 49 . From d 42 to 48 calves were fed $1.9 \mathrm{~L}$ of pasteurized milk in the morning only. At the weaning day calves had a daily intake of grain of at least $0.9 \mathrm{~kg}$. After weaning, calves were kept in the hutches for $10 \mathrm{~d}$ more before being turned out to group pens of 8 to 10 animals. From d 60 to 75 , calves were fed 2.3 to $3.2 \mathrm{~kg} / \mathrm{d}$ of calf starter top dressed with chlortetracycline (Aureomycin, Zoetis Inc., Florham Park, NJ), and good-quality hay was provided ad libitum. From d 75 to 130, calves were fed a mixture of TMR and calf starter $(2.3$ to $3.2 \mathrm{~kg} / \mathrm{d}$ of calf starter, and 2.3 to $4.5 \mathrm{~kg} / \mathrm{d}$ of TMR). At about d 130, heifers were consuming about $7.7 \mathrm{~kg} / \mathrm{d}$ of TMR/ calf starter mix and were moved to larger pens of 18 to 20 heifers. At this point, calf starter was no longer provided and heifers were fed 9.1 to $11.3 \mathrm{~kg} / \mathrm{d}$ of TMR up to $1 \mathrm{yr}$ of age. Heifers needed to be at least 1.3 $\mathrm{m}$ tall, weigh more than $340 \mathrm{~kg}$, and be over $13 \mathrm{mo}$ of age at the start of the synchronization protocols. Observations for the current study were collected from AfiFarm Herd Management (Afimilk Ltd., Kibbutz Afikim, Israel) records. Birth weight and survival of 146 calves ( $\mathrm{HT}=74 ; \mathrm{CL}=72$ ) were analyzed. Additionally, BW, withers height, fertility (HT: $\mathrm{n}=34$; $\mathrm{CL}: \mathrm{n}=38$ ), and milk production in the first lactation (HT: $\mathrm{n}=29$; CL: $\mathrm{n}=35$ ) were analyzed. Body weight 
and withers height were measured monthly, from 2 to 12 mo of age. A digital scale was used by farm staff to measure BW. Lactating cows were milked twice daily and milk production was recorded daily up to $35 \mathrm{wk}$ in lactation. Milk composition and SCC was measured using the AfiLab milk analyzer (Afikim Ltd.) at each milking. The AfiLab detects 4 levels of SCC (0-200, 200-400, 400-800, and >800 × $10^{3}$ cells $/ \mathrm{mL}$ ), which were translated into 4 scores (1 to 4 , respectively) and analyzed as weekly averages. Body condition score was evaluated only at calving, and BW was recorded at calving and at each milking until 35 wk postpartum by the AfiFarm system (Afikim Ltd.).

\section{Statistical Analysis}

Birth weight, BW gain, BCS at calving and fertility data were analyzed by ANOVA using the GLM procedure of SAS 9.2 (SAS Institute, Cary, NC). The SAS model included fixed effects of treatment (TRT), year, and conception (AI or IVF) with calf or heifer within the TRT as a random effect. Treatment by year and TRT by conception interactions were included in the model and only retained if significant at the 0.15 level. Sex and TRT by sex interaction were also included in the model for birth weight analysis. Least squares means \pm standard error of the mean are presented, with the greatest standard error of the mean reported. To analyze calf survival, a Chi-squared test was performed using the FREQ procedure of SAS 9.2. Repeated measures data (BW and withers height up to 12 mo of age, BW during lactation, milk yield, milk composition, and SCS) were analyzed by ANOVA using the MIXED procedure of SAS 9.2. The SAS model included fixed effects of TRT, year, conception (AI or IVF), time, and TRT by year, TRT by conception, and TRT by time interactions with heifer within the TRT as a random effect. Season of calving and TRT by season interaction were also included in the model for analyses of milk yield, milk composition, and BW during lactation. April to August was considered season 1 (CL: $\mathrm{n}=19$; HT: $\mathrm{n}=11$ ) and September to February, season 2 (CL: $\mathrm{n}=16$; HT: $\mathrm{n}=18$ ); no heifers calved in March. Differences with $P \leq 0.05$ were considered statistically significant, and those with $P$-values $>0.05$ and $\leq 0.10$ were considered trends.

\section{RESULTS}

\section{Growth Performance and Survival}

Cooled calves were heavier at birth than HT calves ( $44.8 \pm 0.7$ vs. $39.1 \pm 0.7 \mathrm{~kg} ; P<0.001)$. Additionally,
CL heifers were heavier $(P=0.04$; Figure 1$)$ and taller $(111.8 \pm 0.6$ vs. $110.0 \pm 0.7 \mathrm{~cm} ; P=0.03)$ up to $1 \mathrm{yr}$ of age, but had similar total weight gain $(305.8 \pm 6.3$ vs. $299.1 \pm 6.3 \mathrm{~kg}$, respectively; $P=0.44)$ and ADG (0.83 \pm 0.02 vs. $0.81 \pm 0.02 \mathrm{~kg}$, respectively; $P=0.44$ ) from birth to 1 yr of age compared with HT heifers.

The stillborn rate was $4.1 \%$ among HT calves, whereas we had no stillborn cases among CL calves (Table 1). Among bull calves, mortality rate was similar for both treatments $(P=0.35$; Table 1$)$. However, most of the bull calves were sold between birth and 5 mo of age; therefore, the mortality rate is limited to that duration for bull calves. The percentage of heifers leaving the herd before puberty was similar between treatments $(P=0.26)$; however, a smaller percentage of CL heifers left the herd before puberty due to sickness, malformation, or growth retardation $(P=0.03)$. Moreover, a greater percentage of CL heifers completed the first lactation compared with the HT heifers $(P=$ 0.05 ; Table 1).

The reasons for death or euthanasia before 1 mo of age were malformation, septicemia, navel infection, pneumonia, and growth retardation. Reasons for selling heifers before puberty included genetic culling, growth retardation, mastitis, and infantile ovaries. In the HT treatment, the percentage of heifers that left the herd before puberty due to sickness, malformation, or growth retardation tended to be greater among IVF heifers compared with AI heifers (33.3 vs. $10.3 \%$; $P$ $=0.10$ ), and most of them were less than 1 mo of age when they left the herd. There were 3 cases of euthanasia or culling motivated by growth retardation before puberty, all in the HT treatment, and only 1 of these heifers was IVF.

\section{Reproductive Performance and Milk Production}

Reproductive data are summarized in Table 2. No differences were observed between CL heifers and HT heifers for age at first AI $(P=0.32)$. The number of services per pregnancy confirmed at d 30 after insemination was smaller for CL heifers $(P=0.05)$; hence, CL heifers tended to be younger when pregnancy was confirmed $(P=0.07)$. However, number of services per pregnancy confirmed at d 50 after insemination and age at first parturition was not different between treatments. Additionally, CL and HT heifers had similar BCS (3.48 \pm 0.17 vs. $3.47 \pm 0.17$, respectively) at calving.

Compared with HT heifers, CL heifers produced more milk up to $35 \mathrm{wk}$ of the first lactation $(31.9 \pm 1.7$ vs. $26.8 \pm 1.7 \mathrm{~kg} / \mathrm{d} ; P=0.03$; Figure 2 ), but no differences in SCS and percentage of protein, fat, and lactose 
Table 1. Effect of maternal heat stress (HT) or cooling (CL) during late gestation on calf survival

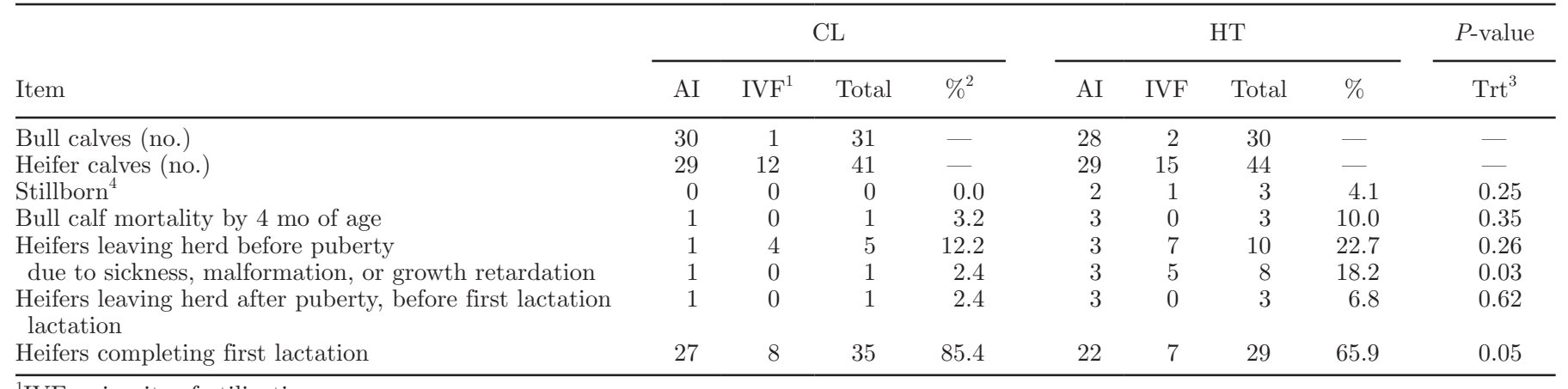

${ }^{1} \mathrm{IVF}=$ in vitro fertilization.

${ }^{2}$ Percentage of animals (AI + IVF) affected out of total animals (males or females) in the respective treatment.

${ }^{3}$ Treatment.

${ }^{4}$ Includes male and female calves.

in milk were observed (Table 3). Calculation of the milk fat-to-protein ratio revealed no difference between the groups (HT: $1.20 \pm 0.02$ vs. CL: $1.19 \pm 0.02 ; P=0.79$ ). There was no effect of calving season on milk production. Additionally, no difference in BW was observed at calving (CL: $562.8 \pm 11.4$ vs. HT: $565.1 \pm 11.4 \mathrm{~kg} ; P$ $=0.89$ ) or during lactation (CL: $566.5 \pm 14.3$ vs. HT: $568.4 \pm 14.3 \mathrm{~kg} ; P=0.92$; Figure 3$)$.

\section{DISCUSSION}

As expected, and in accordance with other studies (Collier et al., 1982; Tao et al., 2012; Monteiro et al., 2014), HT calves were lighter at birth and it was evident that they did not have any compensatory growth before puberty, as they remained smaller and lighter up to $1 \mathrm{yr}$ of age. Because treatment groups did not

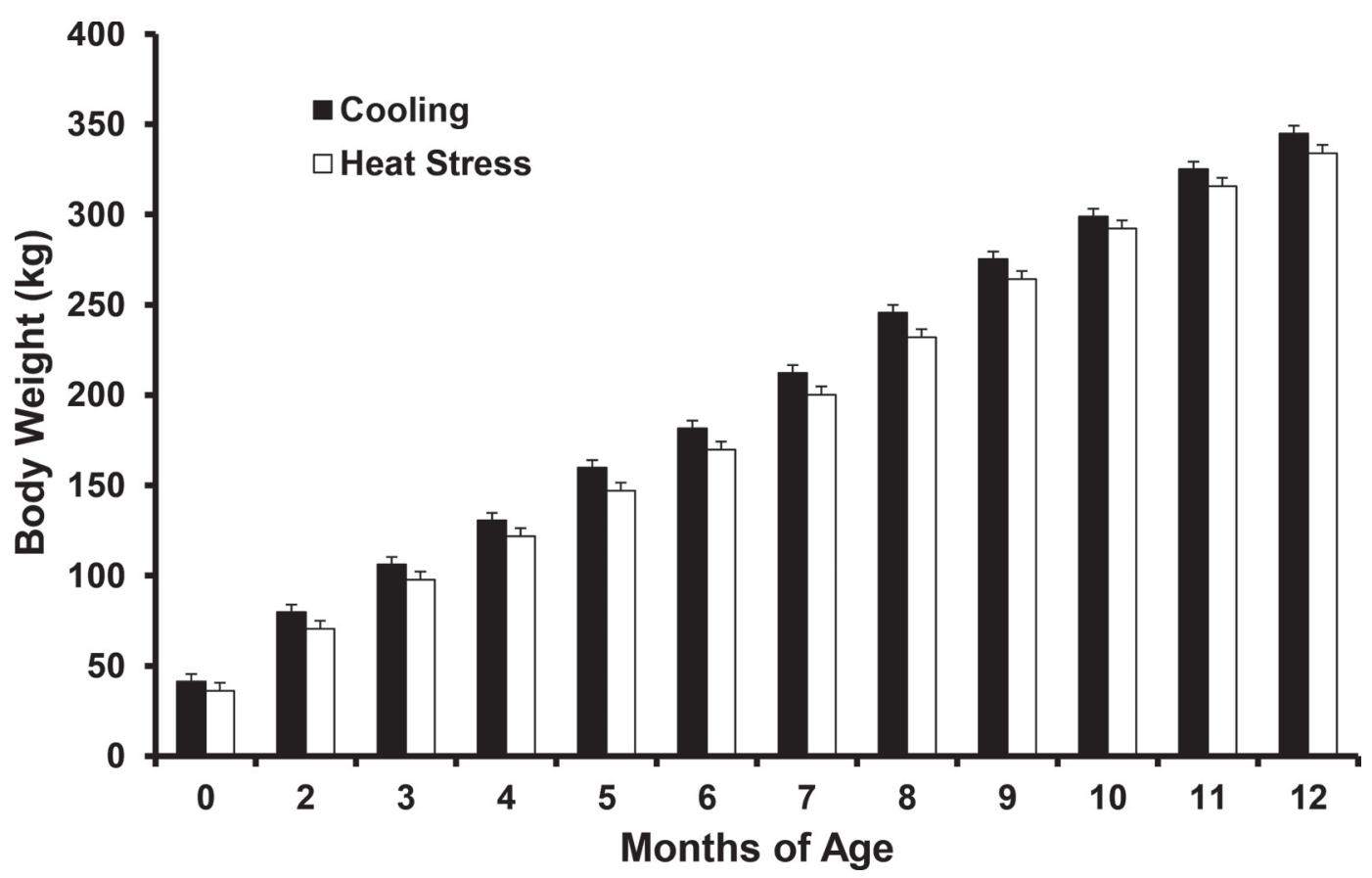

Figure 1. Effect of maternal heat stress $(\mathrm{HT}, \mathrm{n}=34)$ or cooling $(\mathrm{CL}, \mathrm{n}=38)$ during late gestation on BW of heifers up to 1 yr of age. Solid bars $(\square)$ and open bars $(\bigcirc)$ represent calves from cooled dams and heat-stressed dams, respectively. Data from calves born over 5 consecutive years were analyzed. Heifers born to cows exposed to CL during the dry period were heavier $(P=0.04)$ compared with those born to HT cows. Error bars indicate SEM. 


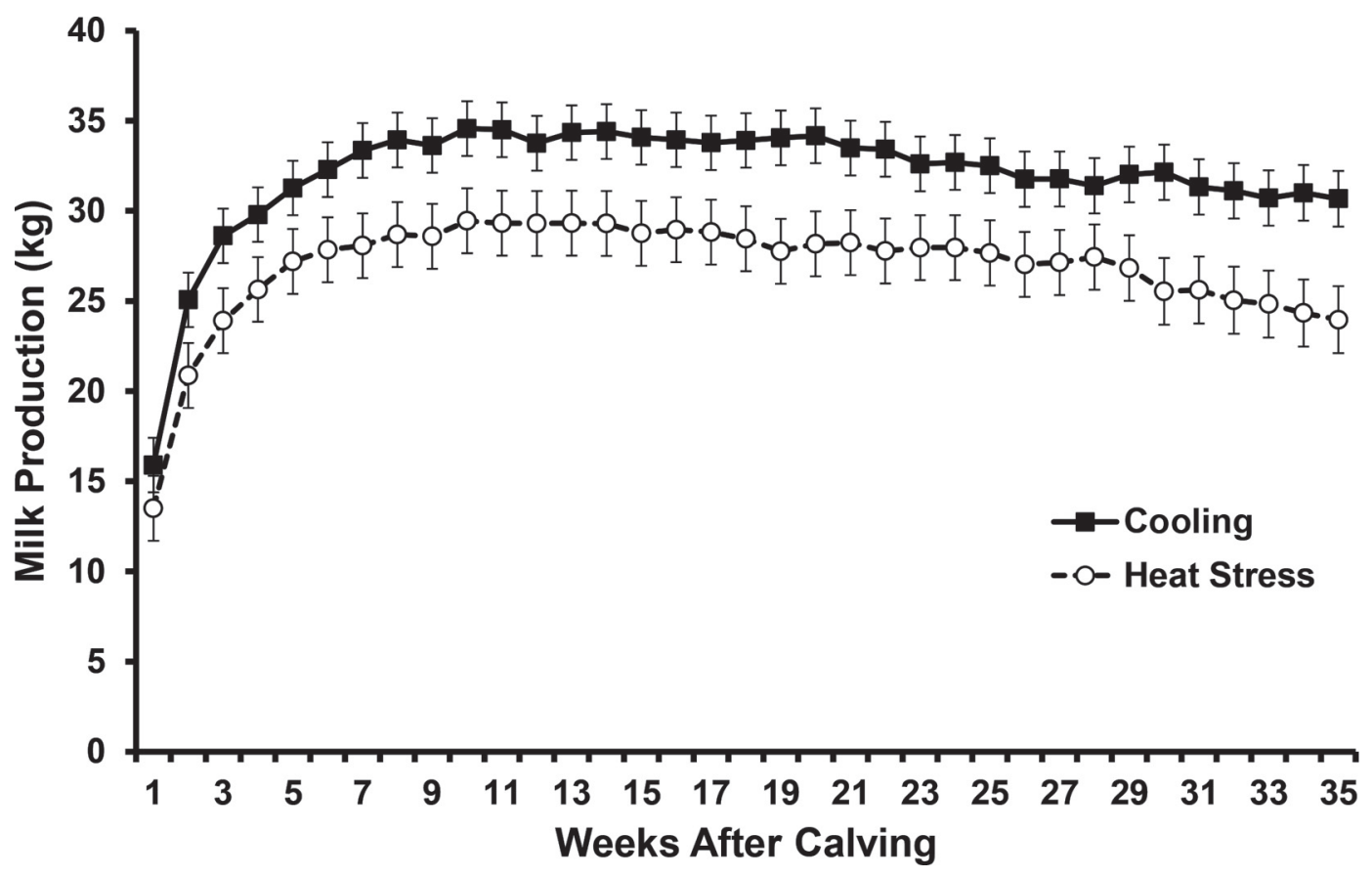

Figure 2. Effect of maternal heat stress $(H T, n=29)$ or cooling $(\mathrm{CL}, \mathrm{n}=35)$ during late gestation on milk production in the first lactation. Solid squares $(\boldsymbol{\square})$ and open circles $(\bigcirc)$ represent calves from cooled dams and heat-stressed dams, respectively. Data from calves born over 5 consecutive years were analyzed. Heifers born to cows in HT during the dry period produced less milk up to 35 wk postpartum compared with those born to cows exposed to CL $(26.8 \pm 1.7$ vs. $31.9 \pm 1.7 \mathrm{~kg} / \mathrm{d} ; P=0.03)$. Error bars indicate SEM.

differ in BW gain up to 12 mo old, it can be concluded (similar to Tao et al., 2012) that the difference in BW observed during the first year after birth is a consequence of the lower birth weight rather than a difference in growth rate. The greater morbidity and mortality observed in HT calves is evidence of the negative effects of maternal heat stress on the health of the offspring. Indeed, Tao et al. (2012) found that calves born to cows heat stressed during the dry period had lower peripheral blood mononuclear cell proliferation during the preweaning period and compromised apparent efficiency of $\operatorname{IgG}$ absorption (19.2 vs. 33.6\%) when compared with those born to cows cooled when dry. It is known that calves born during summer months in Florida have lower total protein concentrations (5.1 vs.

Table 2. Effect of maternal heat stress (HT) or cooling (CL) during late gestation on reproductive performance before first lactation of heifers born to HT or CL dams

\begin{tabular}{|c|c|c|c|c|}
\hline Item & CL & $\mathrm{HT}$ & SEM & $P$-value \\
\hline Heifers (no.) & 36 & 32 & - & - \\
\hline Age at first $\mathrm{AI}(\mathrm{mo})$ & 13.6 & 13.8 & 0.2 & 0.32 \\
\hline Services per pregnancy d $\mathrm{d}^{1} 30$ & 2.0 & 2.5 & 0.2 & 0.05 \\
\hline Age at pregnancy d $\mathrm{d}^{1} 30(\mathrm{mo})$ & 16.1 & 16.9 & 0.3 & 0.07 \\
\hline Services per pregnancy d $\mathrm{d}^{1} 50$ & 2.3 & 2.6 & 0.2 & 0.32 \\
\hline Age at calving (mo) & 24.8 & 25.0 & 0.4 & 0.72 \\
\hline
\end{tabular}

${ }^{1}$ Days after insemination.
$5.7 \mathrm{~g} / \mathrm{dL}$; Donovan et al., 1986), which is associated with greater morbidity (59 vs. $19 \%$ ) and mortality (6.8 vs. $3.3 \%$ ) compared with those born during months of milder temperatures (Naylor et al., 1977; Robison et al., 1988). However, as all of the calves, regardless of in utero heat stress status, were managed under the same circumstances after birth, the differences in morbidity

Table 3. Effect of maternal heat stress (HT) or cooling (CL) during late gestation on milk yield and composition in the first lactation of heifers born to HT or CL dams

\begin{tabular}{|c|c|c|c|c|}
\hline Item & CL & $\mathrm{HT}$ & SEM & $P$-value \\
\hline Heifers (no.) & 35 & 29 & - & - \\
\hline Milk (kg/d) & 31.94 & 26.83 & 1.69 & 0.03 \\
\hline $3.5 \% \mathrm{FCM}^{1}(\mathrm{~kg} / \mathrm{d})$ & 31.88 & 26.80 & 1.54 & 0.01 \\
\hline $\mathrm{ECM}^{2}(\mathrm{~kg} / \mathrm{d})$ & 31.56 & 26.88 & 1.63 & 0.03 \\
\hline Fat $(\%)$ & 3.55 & 3.64 & 0.08 & 0.44 \\
\hline Fat $(\mathrm{kg} / \mathrm{d})$ & 1.12 & 0.95 & 0.06 & 0.02 \\
\hline True protein $(\%)$ & 3.00 & 3.05 & 0.03 & 0.24 \\
\hline True protein $(\mathrm{kg} / \mathrm{d})$ & 0.95 & 0.80 & 0.05 & 0.02 \\
\hline Lactose (\%) & 4.82 & 4.80 & 0.02 & 0.68 \\
\hline Lactose $(\mathrm{kg} / \mathrm{d})$ & 1.54 & 1.28 & 0.08 & 0.02 \\
\hline $\mathrm{SCS}^{3}$ & 1.20 & 1.23 & 0.05 & 0.66 \\
\hline
\end{tabular}

${ }^{1} 3.5 \% \mathrm{FCM}=[(0.4324 \times \mathrm{kg}$ of milk $)+(16.216 \times \mathrm{kg}$ of fat $)]$.

${ }^{2}$ Value corrected for $3.5 \%$ fat and $3.2 \%$ true protein using formula from $\operatorname{NRC}(2001): \mathrm{ECM}=[(0.3246 \times \mathrm{kg}$ of milk $)+(12.86 \times \mathrm{kg}$ of fat $)+$ $(7.04 \times \mathrm{kg}$ of true protein)].

${ }^{3} \mathrm{SCS}$ ranges from 1 to 4 and represents 4 levels of SCC (0-200, 200$400,400-800$, and $>800 \times 10^{3}$ cells $/ \mathrm{mL}$ ). 


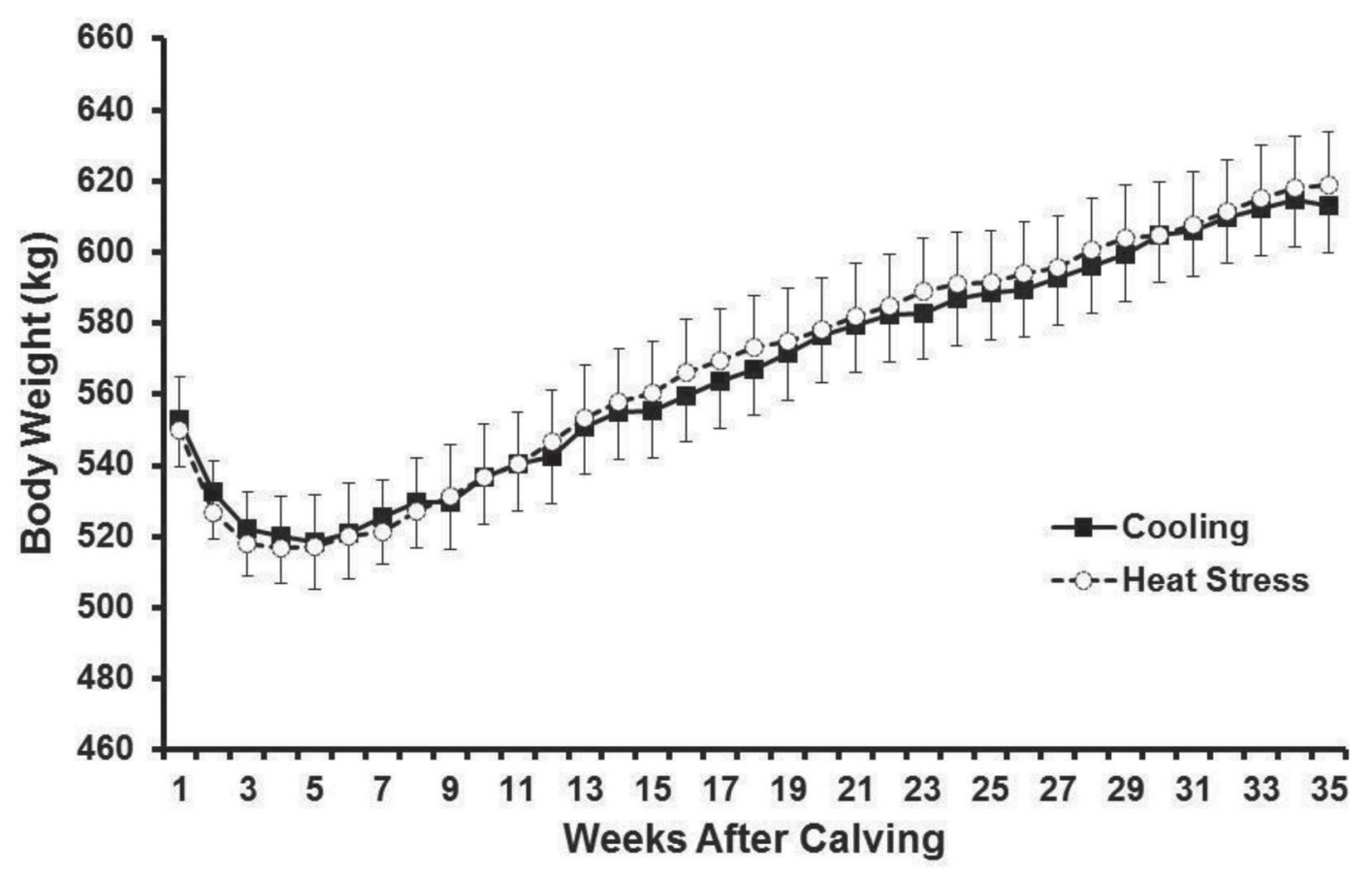

Figure 3. Effect of maternal heat stress $(\mathrm{HT}, \mathrm{n}=27)$ or cooling $(\mathrm{CL}, \mathrm{n}=33)$ during late gestation on BW in the first lactation. Solid squares (-) and open circles $(\bigcirc)$ represent calves from cooled dams and heat-stressed dams, respectively. Data from calves born over 5 consecutive years were analyzed. Heifers born to cows exposed to CL or HT during the dry period had similar BW during lactation (CL: $566.5 \pm 14.3 \mathrm{~kg}$ vs. HT: $568.4 \pm 14.3 ; P=0.92)$ up to 35 wk postpartum. Error bars indicate SEM.

and mortality between treatments is likely related to the prenatal heat stress. The effect of interaction between HT treatment and IVF on calf morbidity and mortality during the prepubertal period is not easily interpreted. But, as the number of IVF calves was evenly distributed in both treatments, we believe that heat stress in utero may have exacerbated the previously identified problems related to calf development, such as growth retardation and incidence of disease, associated with the IVF technique (Bonilla et al., 2014).

The significant and persistently greater output of milk in the first-lactation CL calves compared with HT calves may be explained by several factors, but certainly supports the hypothesis that late gestation in utero heat stress reduces lactation potential. Although no difference between treatments was observed in age at first parturition, the differences observed in number of services per pregnancy confirmed at d 30 after insemination is evidence of an effect of maternal heat stress on fertility before the first lactation. A possible explanation for this difference could be the direct effect of BW on fertility, as heavier heifers seem to become fertile earlier. Archbold et al. (2012) observed that BW of the heifer at mating start date influenced the proportion of heifers pubertal at the start of breeding, as greater BW at mating start date increased the rate of puberty achievement. It is known that lifetime perfor- mance is influenced by early development. Soberon et al. (2012) and Faber et al. (2005) found that greater preweaning growth rate is related to greater firstlactation milk yield. However, Warnick et al. (1995) found no association between calf morbidity and milk production in the subsequent first lactation. The fact that CL heifers were larger than HT heifers at $1 \mathrm{yr}$ of age could explain the differences in milk production, as BW at start of breeding season is associated with subsequent milk solids yield potential (Archbold et al., 2012). Also, it is clear that HT heifers had compensatory growth from 12 mo of age until calving. As reviewed by Lohakare et al. (2012), several studies have observed negative effects of increasing prepubertal BW gains on future milk yield; however, increased growth rate due to high feeding level after puberty and during gestation had no effect on mammary growth and milk yield (Sejrsen et al., 1982, 2000). Because no difference in BW was observed at calving and during lactation in the present study, the difference in milk production is more likely to be explained by differences in mammary gland development and altered metabolic efficiency because of changes in the metabolism of those calves that experienced heat stress in utero. That concept is related to the fact that no difference was noted in milk composition between CL and HT calves, and the yield diverged at calving and remained different through 
lactation. Those observations suggest that mammary capacity was greater in the CL calves, rather than an effect on the activity of the mammary epithelial cells per se. Of course, further work is needed to specifically test those hypotheses.

Heat stress has been shown to induce placental insufficiency intrauterine growth retardation (PI-IUGR) in a sheep model (Yates et al., 2011). Offspring from PI-IUGR animals have major alterations in postnatal metabolism that probably also exist in the offspring from heat stressed cattle during late gestation (Yates et al., 2011). The PI-IUGR offspring express reduced $\beta 2$ adrenergic receptors in the perirenal adipose tissue, caused by elevated catecholamine exposure in utero (Chen et al., 2010). The PI-IUGR lambs have difficulty mobilizing fat and develop greater levels of adipose tissue (Chen et al., 2010). Moreover, PI-IUGR lambs are hypersensitive to glucose stimulation and insulin (Limesand et al., 2006; Thorn et al., 2009), which further increases the probability that glucose will be stored as fat during compensatory growth (Greenwood et al., 1998; Chen et al., 2010); similarly altered metabolic responses were also observed in dairy calves. Tao and Dahl (2013) observed that calves born to cows heat stressed or cooled during the dry period had similar circulating insulin concentrations before colostrum feeding; however, calves from heat-stressed dams had higher insulin concentrations at d 1 after birth when compared with calves from cooled dams. Further, Tao et al. (2014) observed that 55-d-old calves born to heatstressed dams had similar insulin response to a glucose tolerance test and insulin clearance during an insulin challenge, but faster glucose clearance during both challenges; this suggests altered metabolic responses and supports the hypothesis of accelerated lipogenesis and fat deposition during early life in in utero heatstressed calves. In calves, it has been demonstrated that increased fat deposition during the prepubertal period and a higher BCS at breeding are related to lower milk production in the first lactation (Silva et al., 2002). Also, similar to the PI-IUGR sheep model (Chen et al., 2010), in Tao et al. (2012) calves born to cooled or heat-stressed dams during the dry period had similar overall postnatal growth rates. In the present study, the HT heifers never reached the BW of CL calves before puberty; however, we found no difference in $\mathrm{BW}$ at calving and during lactation, indicating that at some point during pregnancy HT heifers did achieve a similar BW to CL heifers. The BCS at breeding was not available, but no difference was observed in BCS at calving, suggesting that fat deposition was similar among treatments at that time.

The data from the present study suggest that lategestation maternal heat stress may alter expression of the fetal genome and have lifelong consequences. This phenomenon is termed fetal programming, where environmental effects, such as maternal gestational stress, can alter the epigenetic state (stable alterations of gene expression through DNA methylation and histone modifications) of the fetal genome and gene expression of imprinted genes (Jaenisch and Bird, 2003; Merlot et al., 2008; Reynolds et al., 2010). It appears that HT in utero results in a metabolically inefficient phenotype relative to CL treatment, as HT calves produced significantly less milk in the first lactation relative to CL calves. Further studies are necessary to determine if these effects persist into subsequent lactations.

\section{CONCLUSIONS}

Maternal heat stress during late gestation decreases calf birth weight and $\mathrm{BW}$ and $\mathrm{WH}$ up to $1 \mathrm{yr}$ of age. Additionally, and consistent with the hypothesis of the study, these data suggest that heat stress during the last 6 wk of gestation negatively affects fertility and milk production up to and through the first lactation of offspring. Epigenetics may provide a molecular mechanism for the effect of in utero heat stress during late gestation on the fetal programming of postnatal growth, disease susceptibility, and milk production. Further studies with a larger number of animals are necessary to fully understand the effects of heat stress in utero on morbidity and mortality in the prepubertal phase. Also, special attention to the metabolism and mammary gland development of those heifers born to cows heat stressed during the dry period is necessary to understand the effect on fertility and milk production in the first lactation.

\section{ACKNOWLEDGMENTS}

The authors thank the staff of the Dairy Unit of University of Florida for animal care and data collection. Support for this study was provided by National Science Foundation (Arlington, VA) Award \#1247362 to G. E. Dahl.

\section{REFERENCES}

Alexander, G., and D. Williams. 1971. Heat stress and development of conceptus in domestic sheep. J. Agric. Sci. 76:53-72.

Archbold, H., L. Shalloo, E. Kennedy, K. M. Pierce, and F. Buckley. 2012. Influence of age, body weight and body condition score before mating start date on the pubertal rate of maiden Holstein and Friesian heifers and implications for subsequent cow performance and profitability. Animal 6:1143-1151.

Bonilla, L., J. Block, A. C. Denicol, and P. J. Hansen. 2014. Consequences of transfer of an in vitro-produced embryo for the dam and resultant calf. J. Dairy Sci. 97:229-239.

Chen, X., A. L. Fahy, A. S. Green, M. J. Anderson, R. P. Rhoads, and S. W. Limesand. 2010. $\beta 2$-Adrenergic receptor desensitization 
in perirenal adipose tissue in fetuses and lambs with placental insufficiency-induced intrauterine growth restriction. J. Physiol. 588:3539-3549.

Collier, R. J., G. E. Dahl, and M. J. Van Baale. 2006. Major advances associated with environmental effects on dairy cattle. J. Dairy Sci. 89:1244-1253.

Collier, R. J., S. G. Doelger, H. H. Head, W. W. Thatcher, and C. J. Wilcox. 1982. Effects of heat stress during pregnancy on maternal hormone concentrations, calf birth weight and postpartum milk yield of Holstein cows. J. Anim. Sci. 54:309-319.

do Amaral, B. C., E. E. Connor, S. Tao, J. Hayen, J. Bubolz, and G. E. Dahl. 2009. Heat stress abatement during the dry period: Does cooling improve transition into lactation? J. Dairy Sci. 92:59885999.

Donovan, G. A., L. Badinga, R. J. Collier, C. J. Wilcox, and R. K. Braun. 1986. Factors influencing passive transfer in dairy calves. J. Dairy Sci. 69:754-759.

Faber, S. N., N. E. Faber, T. C. McCauley, and R. L. Axe. 2005 Effects of colostrum ingestion on lactational performance. Prof. Anim. Sci. 21:420-425.

Greenwood, P. L., A. S. Hunt, J. W. Hermanson, and A. W. Bell. 1998. Effects of birth weight and postnatal nutrition on neonatal sheep: I. Body growth and composition, and some aspects of energetic efficiency. J. Anim. Sci. 76:2354-2367.

Jaenisch, R., and A. Bird. 2003. Epigenetic regulation of gene expression: How the genome integrates intrinsic and environmental signals. Nat. Genet. 33:245-254.

Limesand, S. W., P. J. Rozance, G. O. Zerbe, J. C. Hutton, and W. W. Hay. 2006. Attenuated insulin release and storage in fetal sheep pancreatic islets with intrauterine growth restriction. Endocrinology 147:1488-1497.

Lohakare, J. D., K.-H. Südekum, and A. K. Pattanaik. 2012. Nutrition-induced changes of growth from birth to first calving and its impact on mammary development and first-lactation milk yield in dairy heifers: A review. Asian-australas. J. Anim. Sci. 25:1338 1350.

Merlot, E., D. Couret, and W. Otten. 2008. Prenatal stress, fetal imprinting and immunity. Brain Behav. Immun. 22:42-51.

Monteiro, A. P. A., S. Tao, I. M. Thompson, and G. E. Dahl. 2014 Effect of heat stress during late gestation on immune function and growth performance of calves: Isolation of altered colostral and calf factors. J. Dairy Sci. 97:6426-6439.

Naylor, J. M., D. S. Kronfeld, S. Bech-Nielsen, and R. C. Bartholomew. 1977. Plasma total protein measurement for prediction of disease and mortality in calves. J. Am. Vet. Med. Assoc. 171:635-638.

NRC. 2001. Nutrient Requirements of Dairy Cattle. 7th rev. ed. National Academies Press, Washington, DC.

Oakes, G. K., A. M. Walker, R. A. Ehrenkranz, R. C. Cefalo, and R. A. Chez. 1976. Uteroplacental blood flow during hyperthermia with and without respiratory alkalosis. J. Appl. Physiol. 41:197-201.

Reynolds, L. P., P. P. Borowicz, J. S. Caton, K. A. Vonnahme, J. S. Luther, C. J. Hammer, K. R. Maddock Carlin, A. T. Grazul-Bilska, and D. A. Redmer. 2010. Developmental programming: The concept, large animal models, and the key role of uteroplacental vascular development. J. Anim. Sci. 88:E61-E72.

Reynolds, L. P., P. P. Borowicz, K. A. Vonnahme, M. L. Johnson, A. T. Grazul-Bilska, D. A. Redmer, and J. S. Caton. 2005. Placental angiogenesis in sheep models of compromised pregnancy. J. Physiol. 565:43-58.

Robison, J. D., G. H. Stott, and S. K. DeNise. 1988. Effects of passive immunity on growth and survival in the dairy heifer. J. Dairy Sci $71: 1283-1287$

Sejrsen, K., J. T. Huber, H. A. Tucker, and R. M. Akers. 1982. Influence of nutrition on mammary development in pre- and postpubertal heifers. J. Dairy Sci. 65:793-800.

Sejrsen, K., S. Purup, M. Vestergaard, and J. Foldager. 2000. High body weight gain and reduced bovine mammary growth: Physiological basis and implications for milk yield potential. Domest. Anim. Endocrinol. 19:93-104.

Silva, L. F. P., M. J. VandeHaar, B. K. Whitlock, R. P. Radcliff, and H. A. Tucker. 2002. Short communication: Relationship between body growth and mammary development in dairy heifers. J. Dairy Sci. 85:2600-2602.

Soberon, F., E. Raffrenato, R. W. Everett, and M. E. Van Amburgh. 2012. Preweaning milk replacer intake and effects on long-term productivity of dairy calves. J. Dairy Sci. 95:783-793.

St-Pierre, N. R., B. Cobanov, and G. D. Schnitkey. 2003. Economic losses from heat stress by US livestock industries. J. Dairy Sci. 86(E. Suppl.):E52-E77.

Tao, S., and G. E. Dahl. 2013. Invited review: Heat stress effects during late gestation on dry cows and their calves. J. Dairy Sci. 96:4079-4093.

Tao, S., A. P. A. Monteiro, M. J. Hayen, and G. E. Dahl. 2014. Short communication: Maternal heat stress during the dry period alters postnatal whole-body insulin response of calves. J. Dairy Sci. 97:897-901.

Tao, S., A. P. A. Monteiro, I. M. Thompson, M. J. Hayen, and G. E. Dahl. 2012. Effect of late-gestation maternal heat stress on growth and immune function of dairy calves. J. Dairy Sci. 95:7128-7136.

Thompson, I. M., S. Tao, J. Branen, A. D. Ealy, and G. E. Dahl. 2013. Environmental regulation of pregnancy-specific protein B concentrations during late pregnancy in dairy cattle. J. Anim. Sci. 91:168-173.

Thorn, S. R., T. R. Regnault, L. D. Brown, P. J. Rozance, J. Keng, M. Roper, R. B. Wilkening, and J. E. Friedman. 2009. Intrauterine growth restriction increases fetal hepatic gluconeogenic capacity and reduces messenger ribonucleic acid translation initiation and nutrient sensing in fetal liver and skeletal muscle. Endocrinology 150:3021-3030

Warnick, L. D., H. N. Erb, and M. E. White. 1995. Lack of association between calf morbidity and subsequent first lactation milk production in 25 New York Holstein herds. J. Dairy Sci. 78:2819-2830.

Yates, D. T., A. S. Green, and S. W. Limesand. 2011. Catecholamines mediate multiple fetal adaptations during placental insufficiency that contribute to intrauterine growth restriction: Lessons from hyperthermic sheep. J. Pregnancy 2011:740408. 